Images in...

\title{
Chronic diarrhoea from mycophenolate mofetil-induced colitis
}

\author{
Emmanuel Cruz Gorospe \\ Division of Gastroenterology and Hepatology, Mayo Clinic College of Medicine, Rochester, Minnesota, USA
}

Correspondence to Dr Emmanuel Cruz Gorospe, gorospe.emmanuel@mayo.edu

\section{DESCRIPTION}

A 25-year-old female with mixed connective tissue disease (MCTD) complicated by scleroderma renal crisis presented with a 2 -week history of profuse, watery diarrhoea that persisted through the night and with fasting. She has been maintained on mycophenolate mofetil (MMF) at 1000 $\mathrm{mg} /$ day for 1 year for her MCTD. The patient reported no recent travel or similar illness in her household. There was no associated fever, abdominal pain or blood in the stools. Stool studies were negative for both bacterial and parasitic agents. Flexible sigmoidoscopy showed mild erythema. The colon biopsies revealed apoptosis, crypt distortion and abscess; consistent with MMF-induced colitis (figures 1 and 2). Cytomegalovirus and herpes simplex virus immunostains were negative. During her hospital course, the patient received fluid resuscitation, electrolyte repletion and discontinuation of MMF. Five days later, the patient's stool frequency decreased to twice daily until complete resolution. At 1 month follow-up, her MMF was restarted at a lower dose $(500 \mathrm{mg} /$ day $)$ which was tolerated well without any recurrence of gastrointestinal issues. The presence of typical histopathologic findings, clinical improvement after MMF discontinuation and absence of any alternative cause of diarrhoea support the diagnosis of MMF-induced colitis. ${ }^{1} \mathrm{MMF}$ is an immunosuppressant approved for autoimmune disease and prevention of allograft rejection in transplant patients. The mechanism of MMF-induced colonic injury remains unclear. Although direct MMF colonic cytotoxicity has not been ruled out, it is postulated that the immunosuppressive effects of MMF may indirectly affect lymphocytes in the colon resulting in decreased mucosal protection. ${ }^{2} 3$

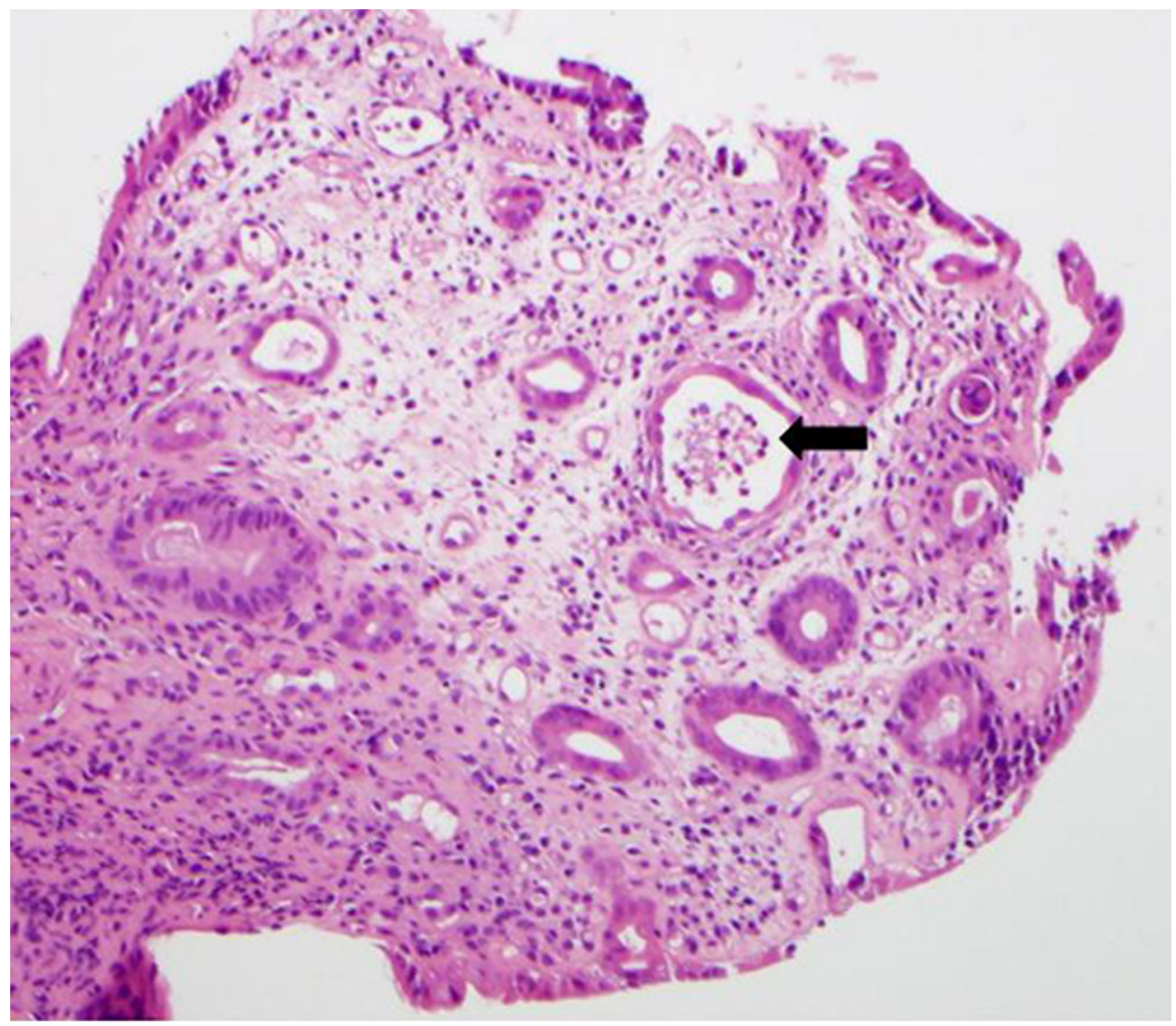

Figure 1 Colon biopsy (H\&E stain): crypt abscess in the centre of the lumen (arrow). 


\section{BMJ Case Reports}

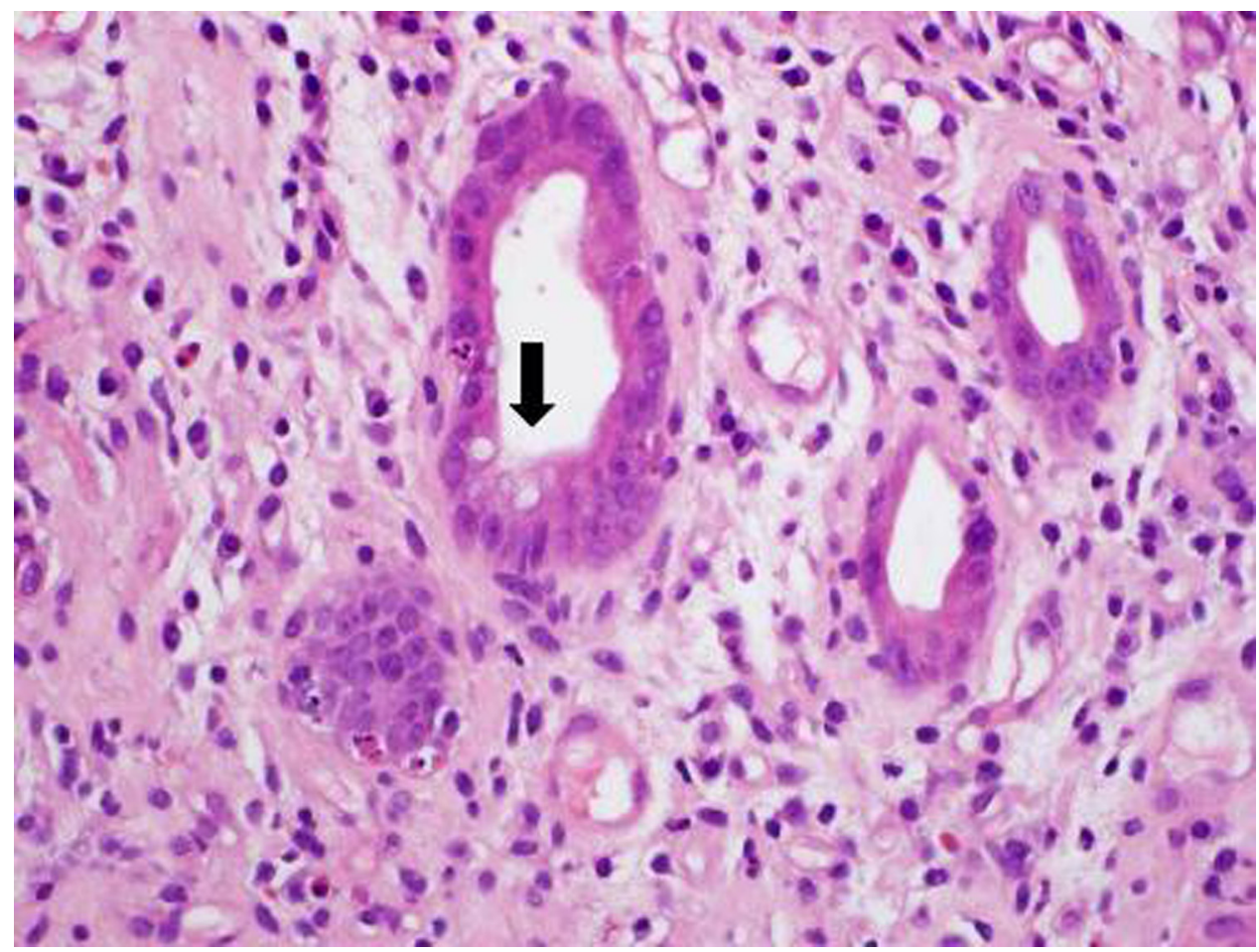

Figure 2 Colon biopsy (H\&E stain): crypt drop-out and distortion (arrow).

\section{Learning points}

- MMF exposure can induce diarrhoea even several months after initiation.

- MMF-induced colitis is defined by clinical and histopathologic characteristics.

- Discontinuation or reduction of MMF dose will usually result in improvement of diarrhoea.

Acknowledgements The author would like to thank Dr Vishal Chandan for providing the histopathology photomicrographs for this case.
Competing interests None.

Patient consent Obtained.

\section{REFERENCES}

1. Al-Absi Al, Cooke CR, Wall BM, et al. Patterns of injury in mycophenolate mofetil-related colitis. Transplant Proc 2010;42:3591-3.

2. Papadimitriou JC, Cangro CB, Lustberg A, et al. Histologic features of mycophenolate mofetil-related colitis: a graft-versus-host disease-like pattern. Int J Surg Pathol 2003;11:295-302.

3. Parfitt JR, Jayakumar S, Driman DK. Mycophenolate mofetil-related gastrointestinal mucosal injury: variable injury patterns, including graft-versushost disease-like changes. Am J Surg Pathol 2008;32:1367-72.

This pdf has been created automatically from the final edited text and images.

Copyright 2012 BMJ Publishing Group. All rights reserved. For permission to reuse any of this content visit

http://group.bmj.com/group/rights-licensing/permissions.

BMJ Case Report Fellows may re-use this article for personal use and teaching without any further permission.

Please cite this article as follows (you will need to access the article online to obtain the date of publication).

Gorospe EC. Chronic diarrhoea from mycophenolate mofetil-induced colitis. BMJ Case Reports 2012;10.1136/bcr.12.2011.5344, Published XXX

Become a Fellow of BMJ Case Reports today and you can:

- Submit as many cases as you like

- Enjoy fast sympathetic peer review and rapid publication of accepted articles

- Access all the published articles

- Re-use any of the published material for personal use and teaching without further permission

For information on Institutional Fellowships contact consortiasales@bmjgroup.com

Visit casereports.bmj.com for more articles like this and to become a Fellow

Keep up to date with all published cases by signing up for an alert (all we need is your email address) http://casereports.bmj.com/cgi/alerts/etoc 